\title{
Електродні матеріали для водневої енергетики
}

\author{
Т.О. Ненастіна ${ }^{1}$, М.В. Ведь ${ }^{2}$, М.Д. Сахненко ${ }^{3}$, С.І. Зюбанова ${ }^{4}$, І.А. Черепньов ${ }^{5}$ \\ ${ }^{1}$ Харківський національний автомобільно-дорожній університет, \\ (м. Харків, Україна) email: nenastina@ukr.net, ORCID: 0000-0001-6108-4023
}

2, 3, 4 Національний технічний університет «Харківський політехнічний університет», (м. Харків, Україна) еmail: 2,4 vmv@kpi.kharkov.ua, ${ }^{3}$ sakhnenko@kpi.kharkov.ua, ORCID: ${ }^{2}$ 0000-0001-5719-6284, ${ }^{3}$ 0000-0002-5525-9525, ${ }^{4}$ 0000-0002-6673-6681

\author{
${ }^{5}$ Харківський національний технічний університет сільського господарства \\ імені Петра Василенка, (м. Харків, Україна) \\ email: voenpred314@ukr.net ORCID: 0000-0003-2421-6503
}

\begin{abstract}
Електроосадження сплавів молібдену, вольфраму і цирконію з кобальтом з білігандних електролітів на імпульсному струмі дозволило отримати композиційні покриття з унікальним поєднанням фізико-хімічних властивостей, недосяжних при використанні інших методів нанесення. Окрім складу отриманих композиційних електролітичних покриттів на каталітичне виділення водню впливають характеристики їх поверхні, зокрема рельєф і морфологія. Дослідження топографії поверхні проводили за допомогою сканівного атомно-силового мікроскопа контактним методом. Порівняно топографію поверхні осаджених покриттів і показано, що найбільш рівномірно розвиненими і мікроглобулярними є композити складу Co-Mo-WOx і Co-Mo-ZrO2. Електролітична реакція виділення водню є багатостадійним процесом, тому для встановлення каталітичної активності композиційних сплавів на основі кобальту необхідно визначити механізм за яким відбувається даний процес. Оцінку електрокаталітичних властивостей композиційних електролітичних покриттів на основі сплавів кобальту різного складу здійснювали на підставі аналізу кінетичних параметрів модельної реакції виділення водню з розчинів електролітів різної кислотності. Визначено постійні Тафеля, коефріцієнти переносу, густину струму обміну для електрохімічного виділення водню на композиційних електролітичних покриттях сплавами кобальту. За величиною струму обміну електрохімічної реакції виділення водню на покриттях Co-Mo-WOx, Co-Mo-ZrO2, Co-W-ZrO2 встановлено їх високу електрокаталітичну активність порівняно із індивідуальними металами і бінарними сплавами. Встановлено, що електровідновлення водню на композиційних сплавах кобальту протікає за механізмом Фольмера-Тафеля з уповільненою стадією рекомбінації. Запропоновано схеми реакцій, за якими протікає відновлення водню, якщо проміжним продуктом загального процесу є гідриди металів.
\end{abstract}

Ключові слова: композиційні покриття, сплави кобальту, виділення водню, постійні Тафреля, воднева енергетика.

Вступ. В останні десятиріччя у зв'язку з виснаженням нафтових запасів перед людством постає питання пошуку альтернативи вуглеводневому паливу [1]. Успіхи в розвитку ряду водневих технологій, зокрема паливних елементів, транспортних систем на водні тощо, продемонстрували, що використання водню приводить до якісно нових показників в роботі систем або агрегатів. По-перше, при згорянні водню у кисневому середовищі утворюється вода, а отже, реагенти і продукти не $є$ токсичними. По-друге, водень має високу теплоту згоряння на одиницю маси (120 МДж/кг) і його легко транспортувати по трубопроводах і зберігати у підземних ємностях. По-третє, за допомогою водню можна акумулювати енергію, що виробляється електростанціями у нічні години та вихідні дні, а також енергію поновлюваних джерел (сонця, вітру). Це $є$ свідченням 
актуальності водневої технології, незважаючи на те, що водень пожежо- та вибухонебезпечний.

По мірі того, як розширювалась область досліджень, пов'язаних з отриманням, зберіганням, транспортом і використанням водню, ставали все більш очевидними екологічні переваги водневих технологій у різних галузях народного господарства. Незважаючи на те, що водень є вторинним енергоносієм, тобто коштує дорожче, ніж природне паливо, його застосування у ряді випадків $€$ економічно доцільним вже зараз. Відомо безліч методів отримання водню, що включають фрізичні процеси його вилучення із сумішей, низькотемпературної конденсації і фракціонування, адсорбційне виділення за допомогою молекулярних сит або рідких розчинників, фотокаталітичні і електрофотокаталітичні методи, термохімічні, термоелектрохімічне і плазмохімічне розкладання води і сірководню. Однак, електроліз води - один з найбільш відомих і добре досліджених методів отримання водню [2].

Електрохімічна технологія стала однією 3 найважливіших, оскільки вона дозволяє отримувати газоподібний водень з чистотою до 99$99,9 \%$. Тому роботи з водневої енергетики у багатьох, особливо промислово розвинених країнах, відносяться до пріоритетних напрямів розвитку науки і техніки $[3,4]$.

При електролітичному отриманні водню витрати електроенергії слід розділити на "корисні", що затрачуються на виділення водню на катоді, i "непотрібні", які пов'язані із виділенням кисню на аноді, величини яких залежать від перенапруги відповідних реакцій [5]. Тому найважливішою проблемою отримання водню електролізом $€$ синтез електродних матеріалів з невисокою перенапругою виділення не тільки водню $\left(\mathrm{H}_{2}\right)$, але і кисню $\left(\mathrm{O}_{2}\right)$. Металевий кобальт має високу електрокаталітичну активність, тому використовується як електродний матеріал при отриманні $\mathrm{H}_{2}$ електролізом води і в паливних елементах $[5,6]$. Крім того, активно використовується нікель у складі металогідридних носіїв водню $\left(\mathrm{LaNi}_{5} \mathrm{H}_{6}, \mathrm{Mg}_{2} \mathrm{NiH}_{4}\right)$, а також у вигляді катодної матриці електролізерів, модифікованої покриттями карбіду вольфраму, молібдену [5] та іншими композитами [7].

В [5] проведено аналіз залежностей струмів обміну і величин перенапруги реакції електрохімічного виділення водню, енергії зв'язку Ме-Н від енергії Фермі та інших функцій і показано, що такі метали як W, Mo, Re, Sb, Co, Ni, Ru, Au, Pd, Os, $\mathrm{Pt}, \mathrm{Rh}$, мають низьке значення перенапруги виділення водню. Отже, можна припустити, що при нанесенні тонких покриттів цими металами та їх сплавами на поверхню електродів можна забезпечити низьку перенапругу для реакції електролітичного виділення водню.
У цій статті наведені результати дослідження закономірності виділення водню на композиційних електрохімічних покриттях Co-Mo-WOx, Co$\mathrm{Mo}-\mathrm{ZrO}_{2}$ і $\mathrm{Co}-\mathrm{W}-\mathrm{ZrO}_{2}$.

Методика проведення експерименту. Осадження композиційних електрохімічних покриттів (КЕП) на основі сплавів кобальту Co-Мо$\mathrm{WO}_{x}, \mathrm{Co}-\mathrm{Mo}_{\mathrm{Z}} \mathrm{ZrO}_{2}, \mathrm{Co}-\mathrm{W}-\mathrm{ZrO}_{2}$ проводили $з$ цитратно-пірофросфатних електролітів [2, 9] уніполярним імпульсним струмом амплітудою 4 A/дм² і частотою $f=83,3 \mathrm{~Hz}$. За допомогою потенціостата ПІ-50-1.1 і програматора ПР-8 задавали режими електроосадження покриттів і реєстрували поляризаційні залежності. Як розчинні аноди використовували паралельно розташовані кобальтові пластини. КЕП наносили на мідну підкладку з робочою площею $1 \mathrm{~cm}^{2}$, підготовчі операції по обробці поверхні зразків проводили за загальноприйнятою методикою [10].

Дослідження топології поверхні проводили за допомогою сканівного атомно-силового мікроскопа (ACM) NT-206 контактним методом з використанням зонда CSC-37, кантиліверу В з латеральною роздільною здатністю 3 нм. Область сканування фіксували у межах 20,0×20,0 мкм, а висоту рельєфу поверхні визначали за розділенням 256 × 256 пікселів. Візуалізацію результатів здійснювали шляхом реконструкції рельєфу у вигляді 3D-topography карт (висота відображена відтінками сірого кольору).

Хімічний склад отриманих покриттів визначали за результатами енергодисперсійної рентгенівської спектроскопії із застосуванням електронно-зондового мікроаналізатора Oxford INCA Energy 350 (збудження рентгенівського випромінювання здійснювали опроміненням зразків пучком електронів з енергією $15 \mathrm{keV}$ ), інтегрованого у систему сканівного електронного мікроскопа (CEM).

Каталітичну активність досліджували у модельних розчинах наступного складу: 1M розчин $\mathrm{Na}_{2} \mathrm{SO}_{4}$ з додаванням $\mathrm{H}_{2} \mathrm{SO}_{4}$ до $\mathrm{pH}=3 ; 3 \%$ -вий розчин $\mathrm{NaCl}(\mathrm{pH}=6,8)$ і $1 \mathrm{M}$ розчин $\mathrm{Na}_{2} \mathrm{SO}_{4} 3$ додаванням $\mathrm{NaOH}$ до $\mathrm{pH}=11$. Допоміжним електродом при поляризаційних вимірюваннях була платинова спіраль, електродом порівняння - хлорид-срібний напівелемент типу ЕВЛ-1М1. Температура електроліту Т $=298$ К. Швидкість розгортки потенціалу на робочому електроді становила 2 мB/c.

Аналіз каталітичної активності композиційних електролітичних покриттів Co-Mo-WOx, Co-Mo$\mathrm{ZrO}_{2}$ і Co-W-ZrO 2 різного складу проводили за показником густини струму обміну реакції електрохімічного відновлення водню $j_{0}\left(\mathrm{H}_{2}\right)$, оскільки ця величина не залежить від потенціалу електрода. 3 цією метою екстраполювали лінеаризовані у тафелівських координатах ділянки катодної 
поляризаційної залежності в інтервалі потенціалів, віддалених від рівноважного на 200-300 мВ. Сталу Тафеля них ділянок залежностей, отриманих за даними паралельних вимірювань для того ж самого матеріалу в ідентичних умовах.

Результати та обговорення. Реакція виділення водню відноситься до числа багатостадійний процесів і залежно від умов (середовище, матеріал електрода, температура) може протікати за різними механізмами. Так, наприклад, на ртутному електроді лімітуючою є стадія розряду іонів гідроксонію з утворенням адсорбованого водню, який в подальшому видаляється через швидку стадію електрохімічної десорбції:

$$
\begin{gathered}
\mathrm{H}_{3} \mathrm{O}^{+}+\overline{\mathrm{e}} \leftrightarrow \mathrm{H}_{\text {aдс }}+\mathrm{H}_{2} \mathrm{O}, \\
\mathrm{H}_{3} \mathrm{O}^{+}+\mathrm{H}_{\text {aдс }}+\overline{\mathrm{e}} \leftrightarrow \mathrm{H}_{2}+\mathrm{H}_{2} \mathrm{O}
\end{gathered}
$$

У лужних розчинах електрохімічна десорбція відбувається за участю молекул води:

$$
\begin{gathered}
\mathrm{H}_{2} \mathrm{O}+\overline{\mathrm{e}} \leftrightarrow \mathrm{H}_{\mathrm{azc}}+\mathrm{OH}^{-}, \\
\mathrm{H}_{\mathrm{azc}}+\mathrm{H}_{2} \mathrm{O}+\overline{\mathrm{e}} \leftrightarrow \mathrm{H}_{2}+\mathrm{OH}^{-} .
\end{gathered}
$$

За певних умов стадія електрохімічної десорбції може стати сповільненою порівняно зі стадією розряду, і виділення водню буде відбуватися за механізмом електрохімічної десорбції (механізм Фольмера-Гейровського). Можливий також механізм виділення водню, при якому повільною $є$ стадія розряду $(1,3)$, а видалення адсорбованого водню відбувається шляхом рекомбінації (механізм Фольмера-Тафеля) за схемою:

$$
2 \mathrm{H}_{\text {aдс }} \leftrightarrow \mathrm{H}_{2} .
$$

У свою чергу при зміненні умов виділення водню сповільненою стадією може виступати рекомбінація (5) при швидкому протіканні стадії розряду (1). Для певного кола електродних матеріалів при відповідних значеннях перенапруги можливий адсорбційно-електрохімічний механізм, першою стадією якого $є$ адсорбція молекул водню (5) з розчину на поверхні електрода з подальшою електрохімічною десорбцією (2). Крім того, електрохімічна стадія може протікати з одночасним перенесенням двох електронів:

$$
\mathrm{H}_{3} \mathrm{O}_{(\text {пов) }}^{+}+2 \overline{\mathrm{e}} \leftrightarrow \mathrm{H}_{2 \text { (пов) }}+\mathrm{OH}^{-}
$$

або

$$
2 \mathrm{H}_{3} \mathrm{O}^{+} \text {(пов) }+2 \overline{\mathrm{e}} \leftrightarrow \mathrm{H}_{2 \text { (пов) }}+2 \mathrm{H}_{2} \mathrm{O} .
$$

Можливий і стадійне приєднання електронів за відповідною схемою:

$$
\begin{gathered}
\mathrm{H}_{3} \mathrm{O}_{(\text {пов) }}^{+}+\overline{\mathrm{e}} \leftrightarrow \mathrm{H}_{3} \mathrm{O}_{\text {(пов) }}, \\
\mathrm{H}_{3} \mathrm{O}_{\text {(пов) }}+\overline{\mathrm{e}} \leftrightarrow \mathrm{H}_{2 \text { (пов) }}+\mathrm{OH}^{-} .
\end{gathered}
$$

Той чи інший механізм виділення водню залежить від значень перенапруги і від енергії зв'язку адсорбованого атома водню з поверхнею металу. Висновок про справжню природу процесу катодного виділення водню може бути зроблений шляхом аналізу експериментальних даних на підставі порівняння кінетичних закономірностей, що випливають з механізму.

На каталітичне виділення водню впливає як склад отриманих покриттів, так і характеристики їх поверхні. Раніше було встановлено, що до складу покриттів сплавами кобальту поряд із основними компонентами входять кисень і вуглець [11]. Причому, вміст вуглецю практично не залежить від режимів осадження і складу сплаву, але спостерігається тенденція до збільшення відсотка цирконію і кисню при підвищенні густини струму. Імовірно, причиною ефректу, що спостерігається, $€$ послідовність стадій співосадження компонентів і інтенсифікація паралельної реакції виділення водню при високій поляризації, яка викликає залуження приелектродного шару.

Завдяки значній кількості кисню у складі сплавів на основі кобальту, який пов'язаний із неповним відновленням вольфрамат- або молібдат- іонів і гідролізом цирконію (IV), а також нерівномірним розподілом компонентів сплаву по поверхні, такі системи можна розглядати як КЕП складу Co-W-ZrO2, Co-Mo-ZrO2 i Co -Mo-WOx.

Досить вичерпну інформацію про адсорбційну здатність дає аналіз топографії поверхні електролітичних покриттів. У матеріалознавстві шорсткість виступає характеристикою якості поверхні і залежить від способу обробки матеріалу. При осадженні гальванічних покриттів цей параметр не тільки відтворює ступінь шорсткості підкладки, але закономірно пов'язаний із механізмом процесу зародкоутворення на підкладці з чужорідного матеріалу і характером зростання кристалів при фрормуванні сплаву. Тому шорсткість і топографрія $€$ індикатором рівня розвинення поверхні [12]. Аналіз результатів атомно-силової мікроскопії (рис. 1) свідчить, що сплави Co-Mo-WOx відрізняються більш глобулярною і розвиненою поверхнею порівняно із КЕП, що містять в своєму складі оксид цирконію (Co-Mo-ZrO $2, \mathrm{Co}-\mathrm{W}-\mathrm{ZrO}_{2}$ ). У той же час для останніх характерний більший перепад висот.

Аналіз результатів вивчення виділення водню на зразках з синтезованими КЕП показав, що в дослідженому інтервалі потенціалів катодні поляризаційні залежності лінеаризуються у тафелівських координатах. Електрокаталітичні властивості КЕП Co-Mo-WO і Co-Mo-ZrO2 (рис. 2 a, в) відрізняються від таких для $\mathrm{Co}-\mathrm{W}-\mathrm{ZrO}_{2}$ (рис. 2 б), що особливо помітно проявляється у лужному середовищі. Очевидно, така поведінка пояснюється більш істотним впливом молібдену на процес 
виділення водню саме в лужному середовищі, оскільки для даних КЕП вміст молібдену в складі електролітичних сплавів практично однаковий. Крім того, покриття Co-Mo-WO і Co-Mo-ZrO2 мають більш рівномірно розвинену мікроглобулярну поверхню порівняно із $\mathrm{Co}-\mathrm{W}-\mathrm{ZrO}_{2}$.

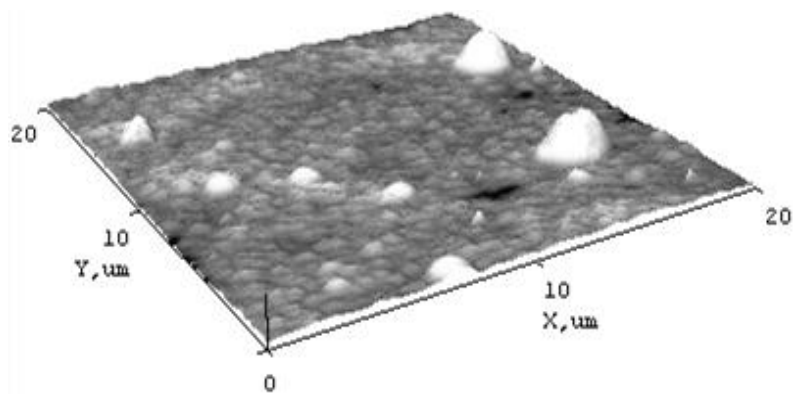

a

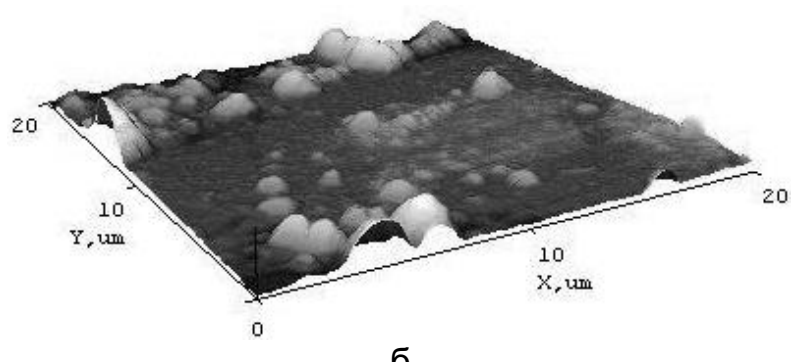

6

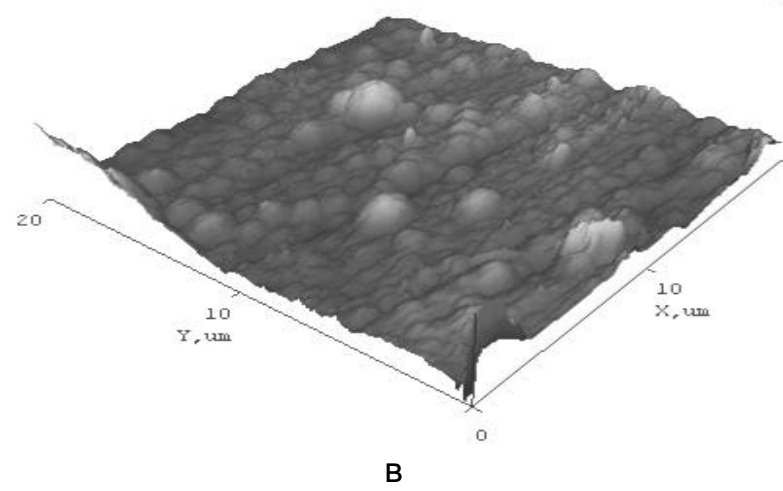

Рис. 1. 3D-карти поверхні покритів Co-Mo-WOx (a), Co-W-ZrO2 (б) i Co-Mo-ZrO2 (в)

Постійна Тафеля $\left(b_{k}\right)$ незалежно від кислотності розчину і складу КЕП становить 0,4-0,5 В (табл.), що вказує на сповільнену стадію розряду і відведення атомів водню шляхом рекомбінації, що відповідає механізму Фольмера-Тафеля. Це підтверджує відомий факт, що для металів підгрупи заліза, які володіють високою адсорбційною здатністю по відношенню до водню, найбільш імовірним буде видалення атомів водню каталітичною рекомбінацією.

Величина а змінюється у широких межах від 1,6 до 3,0, що пов'язано із наявністю на поверхні композиційних електролітичних покриттів оксидів металів та недостатньою питомою поверхнею зразків (рис.1).

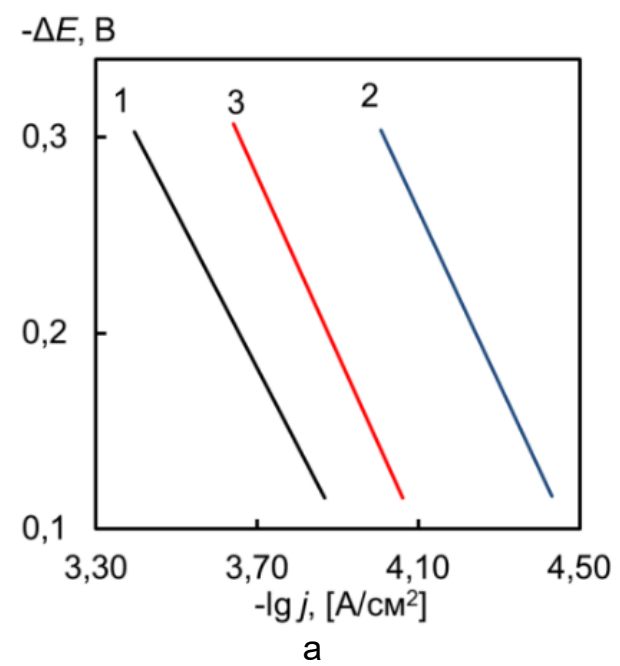

$-\Delta E, B$

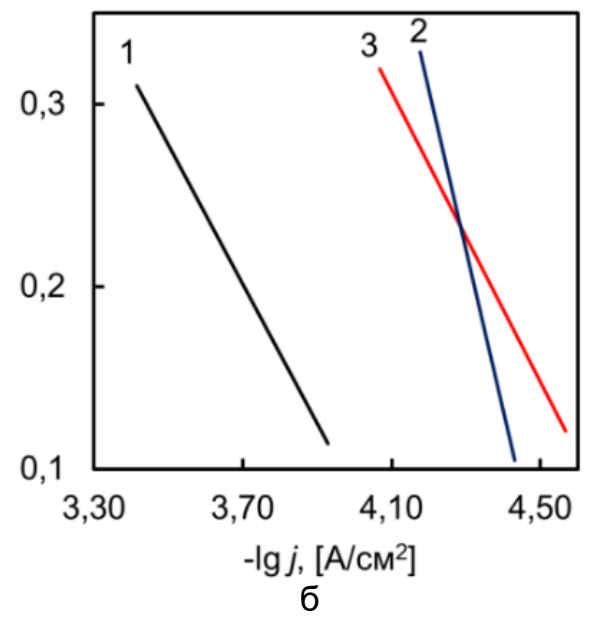

$-\Delta E, \mathrm{~B}$

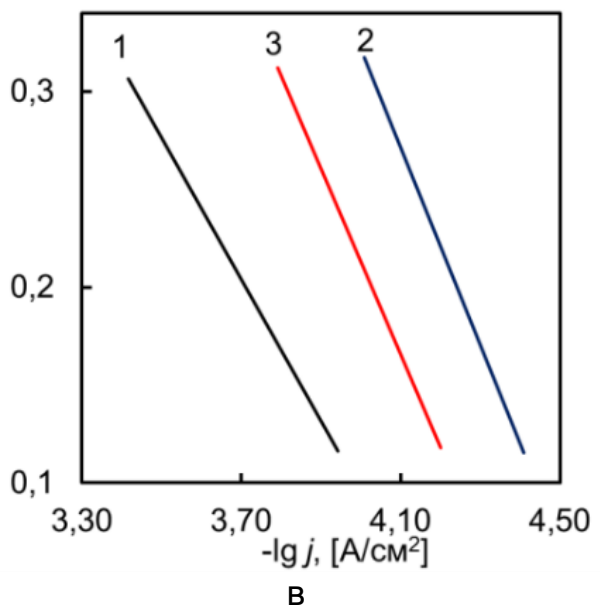

Рис. 2. Перенапруга виділення водню в кислому (1), нейтральному (2) і лужному середовищах (3) на КЭП Co71Mo20W9 (a),

Co85W14Zr1 (б) і Co80Mo19Zr1 (в) 
Елементарні Co, W і Мо мають нанодисперсному природу і тому більш активно взаємодіють із адсорбованим атомарним воднем, який безперервно утворюється в процесі електролізу по одноелектронному механізму Фольмера. Атомарному водню, як випливає з його стандартного електродного потенціалу $E_{\mathrm{H}^{+} / \mathrm{H}}^{0}=-2,1065 \mathrm{~B}$, притаманна висока реакційна здатність, що сприяє утворенню моногідридів $\mathrm{CoH}, \mathrm{WH}$ і $\mathrm{MOH}$ за хімічним механізмом. Утворення моногідридів металів обумовлює зниження перенапруги виділення водню на нікелі та сплавах кобальту [14].
Для досліджуваного діапазону $\mathrm{pH}$ значення густини струму обміну водню на електродах 3 КЕП Co-Mo-WO $\mathrm{WO}$, Co-Mo-ZrO $\mathrm{Zr}_{2}$ i Co-W-ZrO $\mathrm{Zr}_{2}$ близькі до показників нанодисперсного кобальту (табл.). У той же час, найбільшу каталітичну активність у кислому середовищі, що перевищує показники сплавотвірних металів, проявляє КЕП Co71Mo20W9. Розрахований за результатами експериментальних даних коефіцієнт переносу (а) для реакції виділення водню на електродах 3 КЕП знаходиться у межах 0,1-0,2 залежно від складу сплавів і кислотності середовища.

Таблиця 1 Залежність кінетичних параметрів реакції виділення водню від складу композиційних електролітичних покриттів на основі сплавів кобальту

\begin{tabular}{|c|c|c|c|c|c|c|c|c|c|}
\hline \multirow{3}{*}{$\begin{array}{c}\text { Електродний мате- } \\
\text { риал, склад ме- } \\
\text { тала, мас. \% }\end{array}$} & \multicolumn{9}{|c|}{ Середовище } \\
\hline & \multicolumn{3}{|c|}{ кисле } & \multicolumn{3}{|c|}{ нейтральне } & \multicolumn{3}{|c|}{ лужне } \\
\hline & $-a, B$ & $-b, \mathrm{~B}$ & $\begin{array}{c}\lg i_{\mathrm{H}}^{0} \\
{\left[\mathrm{~A} / \mathrm{cm}^{2}\right]}\end{array}$ & $-a, B$ & $-b, \mathrm{~B}$ & $\begin{array}{c}\lg i_{\mathrm{H}}^{0} \\
{\left[\mathrm{~A} / \mathrm{cm}^{2}\right]}\end{array}$ & $-a, B$ & $-b, \mathrm{~B}$ & $\begin{array}{c}\lg i_{\mathrm{H}}^{0} \\
{\left[\mathrm{~A} / \mathrm{cm}^{2}\right]}\end{array}$ \\
\hline Pt100 [13] & 0,1 & 0,03 & $-3,33$ & - & - & - & 0,31 & 0,10 & $-3,10$ \\
\hline Co100 [13] & 0,62 & 0,14 & $-4,4$ & - & - & - & 0,6 & 0,14 & $-4,3$ \\
\hline Mo100 [13] & 0,66 & 0,08 & $-8,2$ & - & - & - & 0,67 & 0,14 & $-4,8$ \\
\hline W100 [13] & 0,43 & 0,1 & $-4,3$ & - & - & - & - & - & - \\
\hline Co71Mo20W9 & 1,6 & 0,38 & $-4,0$ & 1,9 & 0,46 & $-4,2$ & 2,0 & 0,44 & $-4,7$ \\
\hline Co85W14Zr1 & 1,6 & 0,39 & $-4,2$ & 3,0 & 0,50 & $-4,5$ & 1,9 & 0,39 & $-4,8$ \\
\hline Co80Mo19Zr1 & 1,5 & 0,36 & $-4,2$ & 2,3 & 0,50 & $-4,6$ & 2,1 & 0,43 & $-4,8$ \\
\hline
\end{tabular}

Виходячи з отриманих результатів, реакції, що протікають на електродах з КЕП на основі сплавів кобальту в кислому (10) і лужному (11) середовищах, можна представити наступними схемами:

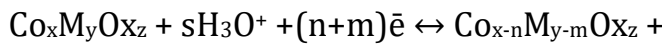

$$
\begin{aligned}
& +\mathrm{nCoH}_{\mathrm{azc}}+\mathrm{mMH}_{\text {aдс }}+(\mathrm{s}-(\mathrm{n}+\mathrm{m})) \mathrm{H}_{2} \mathrm{O} \text {, } \\
& \mathrm{Co}_{\mathrm{x}} \mathrm{M}_{\mathrm{y}} \mathrm{Ox}_{\mathrm{z}}+\mathrm{sH}_{2} \mathrm{O} \leftrightarrow \mathrm{Co}_{\mathrm{x}-\mathrm{n}} \mathrm{M}_{\mathrm{y}-\mathrm{m}} \mathrm{Ox}_{\mathrm{z}}+ \\
& +\mathrm{nCoH}_{\text {адс }}+\mathrm{mMH}_{\mathrm{azc}}+(\mathrm{s}-(\mathrm{n}+\mathrm{m})) \mathrm{OH}^{-} \text {, } \\
& \mathrm{Co}_{\mathrm{x}-\mathrm{n}} \mathrm{M}_{\mathrm{y}-\mathrm{m}} \mathrm{Ox}_{\mathrm{z}}+\mathrm{nCoH} \mathrm{H}_{\text {адс }}+\mathrm{mMH}_{\mathrm{aдc}} \leftrightarrow \\
& \leftrightarrow \mathrm{Co}_{\mathrm{x}} \mathrm{M}_{\mathrm{y}} \mathrm{Ox}_{\mathrm{z}}+((\mathrm{n}+\mathrm{m}) / 2) \mathrm{H}_{2}
\end{aligned}
$$

де M - Мо, W; Ox - оксиди вольфраму або цирконію.

Висновки. Таким чином, за результатами експериментальних досліджень встановлено закономірності катодного виділення водню на композиційних електролітичних покриттях Co-Mo-WOx, Co-Mo-ZrO2 i Co-W-ZrO2. Визначено кінетичні параметри реакції виділення водню на означених тонко плівкових матеріалах - кутові коефіцієнти тафелевскіх залежностей, коефіцієнти переносу, струми обміну. На підстав аналізу кінетичних закономірностей запропоновано механізм виділення водню. Синтезовані КЕП можна рекомендувати як активні шари для електродів, що використовуються при синтезі водню.

\section{Література:}

1. Ведь М.В. Каталітична активність електролітичного сплаву Co-W в гетерогенних окисно-відновних реакціях / Ведь М.В., Байрачна Т.М., Caхненко М.Д., Симоненко О.В. // Вопросы химии и химической технологии. -2008. - № 4. - С. 186 - 190.

2. Берзан В.П. О фризико-энергетических процессах при электролитическом разложении воды/ Берзан В.П., Анисимов В.К. // Проблемы региональной енергетики. - 2006. - №1. - С.87 - 97.

3. Кулешов В.Н. Разработка новых электрокатализаторов для низкотемпературного электролиза воды / Кулешов В.Н., Коровин Н.В., Кулешов Н.В., Удрис Е.Я., Бахин А.Н. // Электрохимическая энергетика. - 2012. - Т.12, № 2. - С. 51 - 58.

4. Козин Л.Ф. Кинетика и механизм выделения водорода на никелевом электроде, модифицированном сплавом никель-вольфрам / Козин Л.Ф., Маликова Н.В. // Украинский химический журнал. - 2009. - Т.75, № 10. - С. 106 - 115.

5. Козин Л.Ф. Современная енергетика и экология: проблемы и перспективы / Козин Л.Ф., Волков С.В. - Киев: Наук. думка, 2006. - 256с. 
6. Сокольский Д.В. Гидрирование в растворах / Сокольский Д.В. - Алма-Ата: Изд-во АН Каз.ССР, 1979. - 240 с.

7. Святкин Л.А. Взаимное влияние водорода и вакансий в $\alpha$-цирконии на энергетику их взаимодействия с металлом / Л.А. Святкин, , Ю.М. Коротеев, И.П. Чернов // Физика твердого тела.2018.- T. 60, № 1. - C.13 - 21.

8. Ved M.V. Nanostructured functional coatings of Iron family metals with refractory elements / M.V. Ved, N.D. Sakhnenko, I.Y. Yermolenko, T.A. Nenastina // International Conference on Nanotechnology and Nanomaterials. - 2017.- P. 3 - 34.

9. Yar-Mukhamedova G. Electrodeposition and properties of binary and ternary cobalt alloys with molybdenum and tungsten / G. Yar-Mukhamedova, M. Ved', N. Sakhnenko, T. Nenastina // Applied Surface Science. - 2018. - Vol. 445.- pp. 298 - 307.

10. Sakhnenko N.D. Functional coatings of ternary alloys of cobalt with refractory metals / N.D. Sakhnenko, M.V. Ved, Y.K. Hapon, T.A. Nenastina // Russian Journal of Applied Chemistry. - 2015. - Vol. 88. - P. 1941 - 1945.

11. Ved' M. Corrosion behavior of the electrolytic ternary cobalt alloys with $\mathrm{Mo}(\mathrm{W})$ and $\mathrm{Zr}$ in alkaline solution /M. Ved', N. Sakhnenko, T. Nenastina, I. Yermolenko, V. Proskurina, M. Volobuyev // Ukrainian Chemistry Journal. -2019-T. 85, № 12 . - C.96 - 109.

12. Tabakovic I. Influence of Surface Roughness and Current Efficiency on Composition Gradients of Thin NiFe Films Obtained by Electrodeposition Electrochemical/Electroless Deposition /[I. Tabakovic, J. Gong, S. Riemer, and M. Kautzky // J. Electrochem. Soc. - 2015. Vol. 162. - P. D102 - D108.

13. Фрумкин А.Н. Избранные труды: Перенапряжение водорода / А.Н. Фрумкин. - М.: Наука, 1988. - 240 с.

14. Козин Л.Ф. Закономерности выделения водорода на катодах модифицированных сплавом Мо-Со / Козин Л.Ф., Машкова Н.В., Манилевич Ф.Д. // Физикохимия поверхности и защита материалов. - 2010. - Т.46, №5. - С.454 - 460.

\section{Reference:}

1. Ved' M.V. Katalitichna aktivnist' elektrolitichnogo splavu Co-W v geterogennih okisno-vidnovnih reakcijah / Ved' M.V., Bajrachna T.M., Sahnenko M.D., Simonenko O.V. // Voprosy himii i himicheskoj tehnologii. - 2008. № 4. - S. 186 - 190.

2.Berzan V.P. $\quad$ O fiziko-jenergeticheskih processah pri jelektroliticheskom razlozhenii vody/ Berzan V.P., Anisimov V.K. // Problemy regional'noj energetiki. - 2006. - №1. - S.87 - 97.

3. Kuleshov V.N. Razrabotka novyh jelektrokatalizatorov dlja nizkotemperaturnogo jelektroliza vody / Kuleshov V.N., Korovin N.V., Kuleshov N.V., Udris E.Ja., Bahin A.N. // Jelektrohimicheskaja jenergetika. - 2012. - T.12, № 2. - S. 51 - 58.

4. Kozin L.F. Kinetika i mehanizm vydelenija vodoroda na nikelevom jelektrode, modificirovannom splavom nikel'-vol'fram / Kozin L.F., Malikova N.V. // Ukrainskij himicheskij zhurnal. 2009. - T.75, № 10. - S. 106 - 115.

5. Kozin L.F. Sovremennaja energetika i jekologija: problemy i perspektivy / Kozin L.F., Volkov S.V. - Kiev: Nauk. dumka, 2006. - 256s.

6. Sokol'skij D.V. Gidrirovanie v ras tvorah / Sokol'skij D.V. - Alma-Ata: Izd-vo AN Kaz.SSR, 1979. - 240s.

7. Svjatkin L.A. Vzaimnoe vlijanie vodoroda i vakansij v $a$-cirkonii na jenergetiku ih vzaimodejstvija s metallom / L.A. Svjatkin, Ju.M. Koroteev, I.P. Chernov // Fizika tverdogo tela. - 2018. - T. 60, № 1. $-\mathrm{S} .13$ - 21.

8. Ved M.V. Nanostructured functional coatings of Iron family metals with refractory elements / M.V. Ved, N.D. Sakhnenko, I.Y. Yermolenko, T.A. Nenastina // International Conference on Nanotechnology and Nanomaterials. - 2017.R. 3 - 34 .

9. Yar-Mukhamedova G. Electrodeposition and properties of binary and ternary cobalt alloys with molybdenum and tungsten / G. Yar-Mukhamedova, M. Ved', N. Sakhnenko, T. Nenastina // Applied Surface Science. - 2018. - Vol. 445. - pp. 298 - 307.

10. Sakhnenko N.D. Functional coatings of ternary alloys of cobalt with refractory metals / N.D. Sakhnenko, M.V. Ved, Y.K. Hapon, T.A. Nenastina // Russian Journal of Applied Chemistry. - 2015. - Vol. 88. - R. 1941 - 1945.

11. Ved'M. Corrosion behavior of the electrolytic ternary cobalt alloys with $\mathrm{Mo}(\mathrm{W})$ and $\mathrm{Zr}$ in alkaline solution /M. Ved', N. Sakhnenko, T. Nenastina, I. Yermolenko, V. Proskurina, M. Volobuyev // Ukrainian Chemistry Journal. - 2019 - T. 85, № 12. - S.96 - 109.

12. Tabakovic I. Influence of Surface Roughness and Current Efficiency on Composition Gradients of Thin NiFe Films Obtained by Electrodeposition Electrochemical / Electroless Deposition / I. Tabakovic, J. Gong, S. Riemer, and M. Kautzky // J. Electrochem. Soc. - 2015. - Vol. 162. - P. D102 - D108.

13. Frumkin A.N. Izbrannye trudy: Perenaprjazhenie vodoroda / A.N. Frumkin. - M.: Nauka, 1988. - $240 \mathrm{~s}$.

14. Kozin L.F. Zakonomernosti vydelenija vodoroda na katodah modificirovannyh splavom MoSo / Kozin L.F., Mashkova N.V., Manilevich F.D. // Fizikohimija poverhnosti i zashhita materialov. 2010. - T.46, №5. - S.454 - 460. 


\title{
Аннотация
}

\section{Электродные материалы для водородной энергетики}

\author{
Т.А. Ненастина, М.В. Ведь, Н.Д. Сахненко, С.И. Зюбанова, И.А. Черепнёв
}

Электроосаждение сплавов молибдена, вольфррама и циркония с кобальтом из билигандных электролитов на импульсном токе позволило получить композиционные покрытия с уникальным сочетанием фризико-химических свойств, недостижимых при использовании других методов нанесения. Кроме состава полученных композиционных электролитических покрытий на каталитическое выделение водорода влияют характеристики их поверхности, в частности рельеф и морфология. Исследование топографии поверхности проводили с помощью сканирующего атомно-силового микроскопа контактным методом. Сравнением топографии поверхности осажденных покрытий показано, что наиболее равномерно развитыми и микроглобулярными являются композиты состава Co-Mo-WOx и Co-Mo-ZrO2. Электролитическая реакция выделения водорода является многостадийным процессом, поэтому для установления каталитической активности композиционных сплавов на основе кобальта необходимо определить механизм, по которому происходит данный процесс. Оценку электрокаталитических свойств композиционных покрытий на основе сплавов кобальта различного состава проводили на основании анализа кинетических параметров модельной реакции выделения водорода из растворов электролитов различной кислотности. Определены постоянные Тафеля, коэффициенты переноса, плотность тока обмена для реакции электрохимического выделения водорода на композиционных электролитических покрытиях. По величине тока обмена электрохимической реакции выделения водорода на покрытиях Co-Mo-WOx, Co-Mo-ZrO2, Co-WZrO2 установлено их высокую электрокаталитическую активность по сравнению с индивидуальными металлами и бинарными сплавами. Показано, что электровосстановление водорода на композиционных сплавах кобальта протекает по механизму Фольмера-Тафеля с замедленной стадией рекомбинации. Предложены схемы реакций, по которым протекает восстановление водорода, если промежуточным продуктом общего процесса являются гидриды металлов.

Ключевые слова: композиционные покрытия, сплавы кобальта, выделения водорода, постоянные Тафреля, водородная энергетика.

\section{Abstract \\ Electrode materials for hydrogen energetics}

\section{T.A. Nenastina, M.V. Ved', N.D. Sakhnenko, S.I. Zyubanova, I.A. Cherepnov}

The electrodeposition of molybdenum, tungsten and zirconium alloys with cobalt from biligand electrolytes by pulsed-current made it possible to obtain composite coatings with a unique combination of physicochemical properties unattainable when using other application methods. In addition to the composition of the composite electrolytic coatings obtained, the catalytic evolution of hydrogen is influenced by the characteristics of their surface, in particular the relief and morphology. Surface topography was studied using a scanning atomic force microscope by the contact method. Comparison of the deposited coatings surface topography shows that the most uniformly developed and microglobular are composites of the composition Co-Mo-WOx and Co-Mo-ZrO2. The electrolytic reaction of hydrogen evolution is a multi-stage process, so to determine the catalytic activity of cobalt-based composite coatings, it is necessary to determine the mechanism by which this process occurs. The evaluation of the electrocatalytic properties of composite coatings based on cobalt alloys of different composition was performed on the basis of the analysis of kinetic parameters of the model reaction of hydrogen evolution from electrolytes of different acidity. Tafel constants, transfer coefficients, exchange current density for the electrochemical hydrogen evolution reaction on composite electrolytic coatings was determined. According to the magnitude of the exchange current of the electrochemical reaction of hydrogen evolution on the Co-Mo-WOx, Co-Mo-ZrO2, Co-W-ZrO2 coatings, their high electrocatalytic activity compared to individual metals and binary alloys was established. It is shown that the electro-reduction of hydrogen on composite cobalt alloys proceeds by the Volmer-Tafel mechanism with a slow recombination stage. Schemes of the reactions by which the reduction of hydrogen proceeds, if the intermediate of the common process are metal hydrides, are proposed.

Keywords: composite coatings, cobalt alloys, hydrogen evolution, Tafel constants, hydrogen energetics.

\section{Бібліографічне посилання/ Bibliography citation: Harvard}

Nenastina, T. A. et al. (2020) Electrode materials for hydrogen energetics. Engineering of nature management, (1(15), pp. $6-12$.

Подано до редакції / Received: 12.02.2020 